\title{
PENINGKATAN KEMANDIRIAN BELAJAR MELALUI PEMBELAJARAN SASTRA NUSANTARA BERBASIS PENDIDIKAN KARAKTER TANGGUNG JAWAB
}

\author{
Lizawati, Indriyana Uli \\ IKIP PGRI Pontianak \\ Posel:1izaucu@gmail.com; iyanauli@yahoo.co.id
}

\begin{abstract}
The purpose of this study was to determine the achievement and increase in the independence of literary learning among students through education based learning character responsibility. The research method used is descriptive qualitative with the form of classroom action research. The results of the study obtained an increase in the independence of student learning through character education responsibility. This is seen based on the increase in value from the results of analysis of student learning independence observation sheets that have increased. Judging from the learning outcomes of students of the archipelago literature course. The average student learning independence has increased from $63.57 \%$ with good categories in the first cycle to $81.34 \%$ in the excellent category in cycle II. So that in the second cycle the percentage of each aspect of independence in the observation results fulfills the indicators of success.
\end{abstract}

Keywords: independence of learning; literary archipelago; responsibility character education,.

\begin{abstract}
Abstrak
Tujuan penelitian ini adalah untuk mengetahui pencapaian dan peningkatan kemandirian belajar sastra nusantara mahasiswa melalui pembelajaran berbasis pendidikan karakter tanggung jawab. Metode penelitian yang digunakan adalah deskriftif kualitatif dengan bentuk penelitian tindakan kelas.Hasil penelitian memperoleh peningkatan kemandirian belajar mahasiswa melalui pendidikan karakter tanggung jawab. Hal ini dilihat berdasarkan nilai peningkatan dari hasil analisis lembar observasi kemandirian belajar mahasiswa yang mengalami peningkatan. Dilihat dari hasil belajar mahasiswa mata kuliah sastra nusantara. Adapun rata-rata kemandirian belajar mahasiswa mengalami peningkatan dari 63,57\% dengan kategori baik di siklus I menjadi 81,34\% pada kategori baik sekali di siklus II. Sehingga pada siklus II persentase setiap aspek kemandirian pada hasil observasi memenuhi indikator keberhasilan.
\end{abstract}

Kata Kunci : kemandirian belajar; sastra nusantara; pendidikan karakter tanggung jawab.

\section{PENDAHULUAN}

Kajian sastra lisan dalam pembelajaran sangat erat, hal ini sejalan dengan pengertian sastra lisan, yaitu oral literature yang bermakna kesusastraan yang mencakup ekpresi kesusastraan warga suatu negara. Pembelajaran sastra lisan selama ini belum tersentuh dengan kebudayaan yang penyampaian dan penyebarannya dan diturun-temurunkan secara lisan (dari mulut ke mulut) (Hutomo,1991). Hal itu senada dengan Lord (1976: 1) bahwa sastra lisan adalah sesuatu yang dituturkan dalam masyarakat. Batasan ini memberikan isyarat dalam menyampaikan tradisi lisan unsur melisankan bagi penutur dan unsur mendengarkan bagi penerima menjadi kata kuncinya. Si penutur tidak menuliskan apa yang dituturkan dan penerima tidak membaca apa yang diterimanya.

Pewarisan sastra lisan melalui proses pewarisan turun-temurun oleh sebuah kelompok masyarkat pemilik sastra itu, seperti yang dikemukakan oleh Rusyana (1981) bahwa tradisi lisan adalah tuturan yang sudah berupa tradisi. Tuturan merupakan hasil dari kegiatan berbahasa yang berbentuk frasa, kalimat, dan wacana. Sementara tradisi dipahami 
sebagai kebiasaan turun temurun sekelompok masyarakat yang berdasarkan nilai-nilai budaya masyarakat yang bersangkutan. Tradisi bisa juga berarti adat kebiasaan yang masih dilakukan dan hadir sebagai bagian dari kehidupan masyarakat itu sendiri. Sastra lisan juga merupakan warisan budaya daerah yang diwariskan turun-temurun dan mempunyai nilainilai luhur yang harus dilestarikan. Kehidupan suatu tradisi tidak dapat dipertahankan jika tradisi itu yang oleh masyarakat pendukungnya sudah tidak memberi pengaruh yang signifikan terhadap pola dan sikap kehidupan mereka sehari-hari. Pemerintah tak terkecuali pihak pemerintah harus mampu menjadi pionir gerakan moral untuk bisa terus melestarikan sebuah sastra di daerahnya untuk membangun karakter sebuah bangsa sesuai landasan pancasila. Dalam mengembangkan sebuah sastra lisan yang mampu meanjadi perhatian mahasiswa, bahwa sastra lisan itu penting bagi mereka sebagai objek yang memiliki nilai filosofi hidup dan manfaatnya bisa dirasakan sebagai media untuk mengembangkan diri dalam kancah nasional maupun internasional. Untuk itu antara objek dan metode pembelajaran perlu ditingkatkan untuk memfasilitasi sastra lisan sebagai materi pembelajaran yang menarik dan bermanfaat, tentunya berbasis pendidikan karakter.

Pembelajaran berbasis pendidikan karakter merupakan upaya guru ataau dosen dalam mengajar. Sebagaimana ditegaskan oleh Joice dan Weil (1986) bahwa hakikat mengajar atau teaching, yaitu dalam rangka membantu siswa memperoleh ide, keterampilan, nilai, cara berfikir, sarana untuk mengekspresikan dirinya, dan cara-cara belajar bagaimana belajar. Dalam kenyataanya, hasil akhir atau hasil jangka panjang dari proses pembelajaran adalah "the student's increased capabilities to learn more easly and effectively in the future", yaitu siswa meningkatkan kemampuannya untuk dapat belajar lebih mudah dan lebih efektif dimasa yang akan datang. Oleh karena itu proses pembelajaran tidak hanya memiliki makna deskriptif dan keterkinian, akan tetapi juga bermakna prospektif dan berorientasi masa depan yang membentuk peserta didik memiliki karakter yang berlandaskan pancasila.

Menurut Koesoema (2010) mengemukakan pengertian karakter merupakan struktur antropologis manusia di sanalah manusia menghayati kebebasan dan menghayati keterbatasan dirinya. Dalam hal ini karakter bukan hanya sekadar tindakan saja, melainkan merupakan suatu hasil dan proses. Untuk itu suatu pribadi diharapkan semakin menghayati kebebasannya, sehingga ia dapat bertanggung jawab atas tindakannya baik untuk dirinya sendiri sebagai pribadi atau perkembangan dngan orang lain dan hidupnya. Hakikat pendidikan adalah tercermin pada unsur utama yaitu sikap, proses, produk dan aplikasi. Oleh karena itu pembelajaran yang baik sangat menekankan pada proses, sehingga pendidikan karakter peserta didik tidak hanya berupa hafalan, tetapi mereka juga mampu menerapkan karakter tanggung jawab dalam kehidupannya sehari-hari. Hal tersebut dapat dimunculkan salah satunya melalui pembelajaran sastra nusantara. Tujuan pembelajaran sastra nusantara di atas dapat diwujudkan dengan penerapan pembelajaran berbasis pendidikan karakter tanggung jawab. Salah satu komponen pembelajaran yang berpengaruh terhadap hasil belajar mahasiswa adalah dosennya. Program Studi Pendidikan Bahasa dan Sastra Indonesia IKIP PGRI Pontianak merupakan LPTK yang mencetak guru yang tidak hanya menguasai kompetensi profesional dalam hal kognitif, namun juga diimbangi dengan pendidikan karakter yang sesuai dengan landasan Pancasila. Salah satunya yaitu dengan 
menerapkan pembelajaran sastra nusantara berbasis pendidikan karakter tanggung jawab untuk meningkatkan kemandirian belajar.

Saat ini, sebagian besar pembelajaran sastra nusantara yang dilakukan di IKIP PGRI Pontianak khususnya prodi pendidikan bahasa dan sastra Indonesia kurang mengembangkan kemandirian belajar mahasiswa. Wolters, Pintrich, dan Karabenick (2003) menjelaskan bahwa kemandirian belajar sebagai suatu proses aktif dalam mengkonstruksi dan menetapkan tujuan belajar dan memonitor, mengatur, mengontrol kognisi, motivasi dalam konteks lingkungan. Pembelajaran yang dilakukan guru cenderung membuat siswa tidak mandiri. Karena siswa hanya memperhatikan penjelasan guru, mengikuti cara penyelesaian soal yang dicontohkan guru, dan menjalankan tugas yang diberikan guru.

Pembelajaran yang demikian, membuat mahasiswa menjadi orang yang tergantung dengan orang lain. Mahasiswa menjadi tidak berani menyampaikan ide-ide sastra nusantara yang dimilikinya. Akibatnya potensi sastra lisan mahasiswa tidak dapat berkembang secara optimal. Hal ini tampak dari hasil belajar sastra nusantara mahasiswa yang rendah. Begitu pula, sikap mahasiswa yang rendah terhadap sastra lisannya. Banyak mahasiswa khususnya prodi pendididikan bahasa dan sastra Indonesia di IKIP PGRI Pontianak yang tidak senang terhadap mata kuliah sastra nusantara hal ini terjadi dikarena mahasiswa banyak yang tidak mengetahui sastra lisan yang mereka miliki sesuai dengan daerahnya masing-masing. Untuk meningkatkan kemandirian belajar sastra nusantara, perlu dilakukan perbaikan pembelajaran, dari pembelajaran yang membatasi kemandirian belajar menjadi pembelajaran yang memberikan kesempatan seluas-luasnya bagi mahasiswa untuk mandiri dalam memahami konsep-konsep sastra nusantara maupun dalam melakukan penyelesaian suatu masalah dalam sastra nusantara. Pembelajaran yang dapat mengakomodasi hal tersebut adalah pembelajaran berbasis pendidikan karakter tanggung jawab.

Pembelajaran berbasis pendidikan karakter tanggung jawab memberikan kesempatan yang seluas-luasnya kepada mahasiswa untuk memahami suatu masalah, kemudian melakukan berbagai aktivitas untuk memecahkan masalah tersebut melalui karakter tanggung jawab seperti menyiapkan diri untuk mengikuti perkuliahan dimulai dari mempersiapkan alat tulis, mencari sastra lisan, berdiskusi, melakukan refleksi, dan akhirnya menemukan penyelesaian masalah dan menemukan berbagai konsep, prinsip bertanggung jawab. Tindakan yang digunakan pada pembelajaran berbasis pendidikan karakter tanggung jawab dengan menggunakan lima langkah yaitu: (1) keterlibatan mahasiswa dalam proses pembelajaran, (2) kemauan merespon dan berkreasi dalam pembelajaran, (3) menghargai proses diskusi, (4) keterampilan komunikasi, (5) tangung jawab, dan (6) kesadaran diri/ evaluasi diri.

\section{METODE PENELITIAN}

Penelitian ini dilaksanakan di Program Studi Pendidikan Bahasa dan Sastra Indonesia Fakultas Pendidikan Bahasa dan Seni Keguruan dan Ilmu Pendidikan Persatuan Guru Republik Indonesia (IKIP PGRI) Pontianak Kalimantan Barat. Penelitian akan dilaksanakan pada semester genap Tahun Akademik 2017/2018.

Populasi dalam penelitian ini adalah mahasiswa semester IV Program Studi Pendidikan Bahasa dan Sastra Indonesia IKIP PGRI Pontianak yang terdiri dari 4 kelas. 
Pengambilan sampel dalam penelitian ini adalah kelas A Pagi semester IV dengan teknik cluster sampling. Cluster sampling (teknik klaster sampling) yaitu memilih sampel bukan didasarkan individual tetapi lebih didasarkan pada kelompok, daerah, atau kelompok subjek yang secara alami berkumpul bersama.

Metode yang digunakan dalam penelitian ini adalah metode deskriptif kualitatif dalam bentuk Penelitian Tindakan Kelas (PTK) dengan empat tahapan kegiatan pada setiap siklus yaitu: (1) perencanaan, (2) pelaksanaan, (3) observasi, dan (4) refleksi.. Tindakan yang digunakan pada pembelajaran berbasis pendidikan karakter tanggung jawab dengan menggunakan lima langkah yaitu: (1) keterlibatan mahasiswa dalam proses pembelajaran, (2) kemauan merespon dan berkreasi dalam pembelajaran, (3) menghargai proses diskusi, (4) keterampilan komunikasi, (5) tangung jawab, dan (6) kesadaran diri/ evaluasi diri.

\section{HASIL DAN PEMABAHASAN}

Pelaksanaan penelitian tindakan kelas pada siklus I dan siklus II meliputi empat tahapan yaitu perencanaan, pelaksanaan tindakan, observasi dan refleksi. Selama proses pembelajaran berlangsung peneliti dibantu oleh 2 orang observer yang bertugas melihat dan mencatat segala aktivitas mahasiswa selama proses pembelajaran berlangsung. Penelitian ini menggunakan 1 kelas yaitu kelas A pagi semester IV yang berjumlah 28 mahasiswa dengan model pembelajaran berbasis pendidikan karakter tanggung jawab.

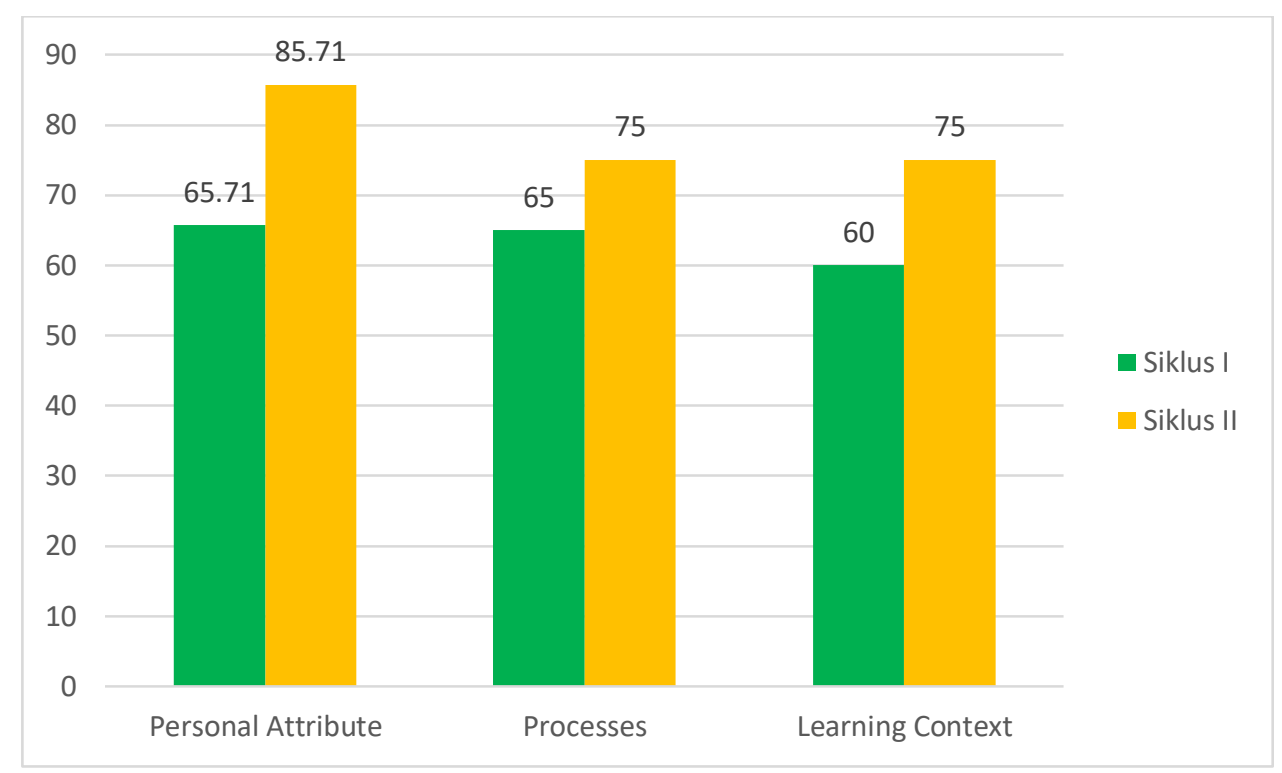

Gambar 1: Hasil Analisis Lembar Observasi Kemandirian Belajar

Berdasarkan hasil penelitian pada Gambar 5.1, dapat dilihat bahwa hasil analisis lembar observasi kemandirian belajar sastra nusantara mahasiswa, aspek personal attributes mengalami peningkatan dari persentase sebesar 65,71\% dengan kategori baik di siklus I menjadi 85,71\% pada kategori baik sekali di siklus II. Aspek processes mengalami peningkatan dari persentase sebesar 65\% dengan kategori baik di siklus I menjadi 75\% pada kategori baik di siklus II. Pada aspek learning context mengalami peningkatan dari persentase 
sebesar 60\% dengan kategori cukup di siklus I menjadi 73,21\% dengan kategori baik pada siklus II. Sedangkan rata-rata kemandirian belajar siswa mengalami peningkatan dari persentase 63,57\% dengan kategori baik di siklus I menjadi 81,34\% pada kategori baik sekali di siklus II. Sehingga pada siklus II persentase setiap aspek kemandirian pada hasil observasi memenuhi indikator keberhasilan. Setelah diberikan penerapan yaitu pembelajaran berbasis pendidikan karakter tanggung jawab berdasarkan Gambar 5.1, menunjukkan bahwa kemandirian belajar mahasiswa mengalami peningkatan.

Peneliti melakukan wawancara dengan lima mahasiswa. Dari hasil wawancara terhadap mahasiswa diketahui bahwa mahasiswa menyukai pembelajaran sastra nusantara berbasis pendidikan karakter tanggung jawab. Menurut mahasiswa pelaksanaan pembelajaran sastra nusantara dapat mempermudah menyelesaikan tugas karena dikerjakan secara berkelompok dan bertanggung jawab. Kegiatan diskusi dan presentasi dapat melatih ketrampilan mahasiswa dalam berkomunikasi dengan menggunakan bahasanya sendiri. Dari hasil wawancara dengan dosen pengampu mata kuliah sastra nusantara diperoleh informasi bahwa mahasiswa sudah dapat melakukan kerja kelompok, komunikasi antar anggota dengan baik, penugasan dalam mengerjakan LKM membuat mahasiswa memiliki tanggung jawab perseorangan, hal tersebut memberikan dampak positif dalam proses pembelajaran yaitu, mahasiswa menjadi lebih mandiri dalam kegiatan belajar.

Berdasarkan catatan lapangan siklus I, proses pembelajaran sastra nusantara berbasis pendidikan karakter tanggung jawab belum berjalan lancar. Hal ini terlihat dari suasana kelas yang kurang kondusif, pengelolaan kelas kurang berjalan baik, namun interaksi antara dosen dan mahasiswa sudah terjalin baik. Namun pada siklus II pelaksanaan pembelajaran sastra nusantara sudah berjalan lancar, suasana kelas kondusif, mahasiswa sudah terbiasa belajar berbasis pendidikan karakter tanggung jawab sehingga kegiatan seperti menggeser kursi dan meja sudah tidak terlalu sering. Pengelolaan kelas berjalan baik, mahasiswa tidak gaduh saat berdiskusi, interaksi antara dosen dan mahasiswa sudah terjalin dengan baik, saat pembelajaran berlangsung dosen selalu memonitor dan mengarahkan mahasiswa dalam berdiskusi.

Berdasarkan hasil penelitian pada siklus I dan siklus II, maka penelitian tidak dilanjutkan ke siklus berikutnya, karena hasil yang diperoleh pada siklus II telah memenuhi indikator keberhasilan yang telah ditetapkan yaitu terjadi peningkatan persentase setiap aspek kemandirian serta persentase rata-rata baik pada hasil observasi kemandirian mencapai batas minimal 70\%. Dengan demikian, penerapan pembelajaran sastra nusantara berbasis pendidikan karakter tanggung jawab dapat meningkatkan kemandirian belajar mahasiswa di kelas A pagi semester IV di IKIP PGRI Pontianak.

\section{SIMPULAN}

Berdasarkan hasil penelitian dapat disimpulkan bahwa ada peningkatan kemandirian belajar melalui pembelajaran sastra nusantara berbasis pendidikan karakter tanggung jawab. Hal ini dilihat berdasarkan nilai peningkatan dari hasil analisis lembar observasi kemandirian belajar mahasiswa yang mengalami peningkatan. Hal ini dapat dilihat dari hasil belajar mahasiswa mata kuliah sastra nusantara. Adapun rata-rata kemandirian belajar mahasiswa mengalami peningkatan dari 63,57\% dengan kategori baik di siklus I menjadi 
81,34\% pada kategori baik sekali di siklus II. Sehingga pada siklus II persentase setiap aspek kemandirian pada hasil observasi memenuhi indikator keberhasilan.

\section{DAFTAR PUSTAKA}

A., Doni Koesoema. (2010). Pendidikan Karakter; Strategi Mendidik Anak di Zaman Global.Jakarta: Grasindo

Hutomo, S.S. (1991). Mutiara Yang Terlupakan. Surabaya: HISKI Jawa Timur.

Joice, B. dan Weil, M. (1986). Models of Teaching. UK: Prentice Hall.

Lord, A.B. (1976). The Singer of Tales. New York: Atheneum.

Rusyana, Y. (1981). Cerita Rakyat Nusantara. Bandung: Fakaultas Keguruan Sastra dan Seni IKIP Bandung.

Wolters, C.A. Pintrich, P.R. dan Karabeninch, S.A. (2003).Assesing Academis Self Regulated Learning. National Institutes of Health March, Michigen. 